\title{
Genetic differentiation among populations of marine algae*
}

\author{
D. J. Innes
}

Department of Biology, University of Windsor; Windsor, Ontario Canada, N9B $3 P 4$

\begin{abstract}
Most of the information for genetic differentiation among populations of marine algae is from studies on ecotypic variation. Physiological ecotypes have been described for individuals showing different responses to temperature and salinity conditions. Morphological ecotypes have also been found associated with areas differing in wave exposure or different intertidal positions. Little is known on how genetic variation is organized within and between populations of marine algae. The occurrence of ecotypic variation in some species is evidence for genetic differentiation among populations resulting from selection by the local environment. The rate of dispersal and subsequent gene flow will also affect the level of differentiation among populations. In species with low dispersal, differentiation can arise through chance founder events or random genetic drift. The few studies available have shown that species of algae exhibit a range of dispersal capabilities. This information can be useful for predicting the potential level of genetic differentiation among populations of these species. Crossing experiments with several species of algae have shown that populations separated by a considerable distance can be interfertile. In some cases individuals from these populations have been found to be morphologically distinct. Crosses have been used to study the genetic basis of this variation and are evidence for genetic differentiation among the populations sampled. Genetic variation of enzyme proteins detected by electrophoresis provides an additional method for measuring genetic variation within and between populations of marine algae. Electrophoretic methods have previously been used to study systematic problems in algae. However, there have been few attempts to use electrophoretic variation to study the genetic structure of populations of marine algae. This approach is outlined and includes some of the potential problems associated with interpreting electrophoretic data. Studies of electrophoretic variation in natural populations of Enteromorpha linza from Long Island Sound are used as an example. This species was found to reproduce only asexually. Despite a dispersing spore stage, genetic differentiation was found on a microgeographic scale and was correlated with differences in the local environment of some of the populations. Similar studies on other species, and especially sexually reproducing species, will add to a growing understanding of the evolutionary genetics of marine algae.
\end{abstract}

\section{INTRODUCTION}

Individuals from geographically separated populations of marine algae are often found to differ morphologically. Geographic variation among populations has resulted in a considerable amount of taxonomic confusion (Mathieson et al., 1981). However, detailed studies of this variation are necessary for understanding how a species can be

\footnotetext{
- Paper presented at the Seaweed Biogeography Workshop of the International Working Group on Seaweed Biogeography, held from 3-7 April 1984 at the Department of Marine Biology, Rijksuniversiteit Groningen (The Netherlands). Convenor: C. van den Hoek.
} 
successfully distributed across a variety of environments. Such studies will ultimately benefit algal systematics and phytogeography.

Morphological variation among individuals from different populations may reflect a response to local environmental conditions. The influence of several common environmental factors on seaweed morphology has recently been reviewed (Norton et al., 1981). The results of these studies show that marine algae have considerable morphological plasticity. Associations between morphological form and specific characteristics of the environment have been used as evidence for an adaptive explanation for this variation (Norton et al., 1982).

Differentiation among populations of a species can be the result of direct modification of the environment or it may reflect underlying genetic differences. Genetic differentiation in turn can result from selection by the environment or simply random events (e.g. random genetic drift, founder events). Ecotypic variation observed within a species has been considered as genetic differentiation resulting from selection in different environments. Morphological and physiological ecotypes have been described for several species of marine algae (Mathieson et al., 1981; Russell \& Fielding, 1981; Bolton, 1983). The genetic basis of this variation has been inferred from observations after one or more generations under common conditions in the laboratory, transplant experiments between sites in the field or outplanting germlings to a common experimental garden in the field. Information on genetic differentiation among populations of algae has also been obtained from attempts to cross individuals from geographically separated populations. Studies on ecotypic variation and interpopulation crossing experiments represent most of the evidence for genetic differentiation among populations of marine algae. Some of these results are discussed here. Since dispersal rate between populations represents an important factor influencing genetic differentiation (Ehrlich \& Raven, 1969), studies on the dispersal potential of some species of algae are also included in this discussion. Finally, the application of electrophoretically detectable genetic variation for studying differentiation among populations of marine algae is presented.

\section{MORPHOLOGICAL DIFFERENTIATION}

Many of the studies on morphological differentiation in algae have been concerned with separating phenotypic plasticity and ecotypic variation within a species from morphological variation between distinct species (Mathieson et al., 1981). Distinguishing these various explanations for morphological variation requires an experimental approach since modification by the environment can parallel any genetic variation. Several approaches have been used to determine the genetic basis of morphological variation and have included transplants between habitats in the field, growth under common conditions in the laboratory or field, laboratory culture followed by outplanting individuals into the field and crosses between different morphological variants. The results of several of these studies (Table 1) provide evidence for genetic differentiation among populations of a species in the form of ecotypic variation (Mathieson et al., 1981; Russell \& Fielding, 1981).

Much of the ecotypic variation observed has been found over short distances, apparently in response to selective pressures from contrasting environments. For example, a large form of Fucus distichus ssp. edentatus was abundant in the lower intertidal, 
Table 1. Genetically based morphological differentiation among populations of marine algae. $C=$ crosses,$L=$ growth under common laboratory conditions, $O=$ growth from spores in the laboratory and outplanted into the field, $T=$ transplants between sites in the field

\begin{tabular}{|lll|}
\hline \multicolumn{1}{|c|}{ Species } & $\begin{array}{c}\text { Evidence for genetic } \\
\text { differentiation }\end{array}$ & \multicolumn{1}{c|}{ Reference } \\
\hline $\begin{array}{l}\text { Antithamnion plumula } \\
\text { (var. plumula and var. bebbii) }\end{array}$ & C, L & $\begin{array}{l}\text { Sundene (1975) } \\
\text { Rueness \& Rueness (1975) } \\
\text { Polysiphonia urceolata }\end{array}$ \\
Ceramium strictum (C. tenuicorne) & L & Kapraun (1979) \\
Enteromorpha intestinalis (E. compressa) & C, L & Rueness (1978) \\
Macrocystis integrifolia & C, L & De Silva \& Burrows (1973) \\
Sargassum cymosum & T & Druehl \& Kemp (1982) \\
Fucus distichus & T & De Paula \& De Oliveira (1982) \\
Laminaria spp. & O & Sideman \& Mathieson (1983) \\
& C, O & Chapman (1974) \\
& & Chapman (1975) \\
& & Lüning et al. (1978) \\
& & Bolton et al. (1983) \\
\hline
\end{tabular}

while a dwarf form predominated in the high intertidal (Sideman \& Mathieson, 1983). Comparisons of the progeny of both forms grown under common conditions in the field revealed that these differences in stature were inherited. The two forms also differed in age of reproductive maturity. The dwarf morph was reproductive after one year, while the larger morph became reproductive after two years. Reproductive differences were thought to be adaptations to the different intertidal environments occupied by the two forms.

Similar differentiation in the intertidal zone was found for Enteromorpha intestinalis. Branched individuals increased in frequency from the high to low intertidal (De Silva \& Burrows, 1973). The degree of branching appeared to have a genetic component since branched and unbranched parents gave rise to predominantly branched and unbranched progeny, respectively.

Populations of several species of algae have been found to become differentiated morphologically in response to local variation in wave exposure (Norton et al., 1981). In some cases, transplant experiments revealed that the morphological variation was due to phenotypic plasticity (Gerard \& Mann, 1979), while other studies indicated the importance of genetic factors (Chapman, 1974; Mathieson et al., 1981; De Paula \& De Oliveira, 1982). Again, such differentiation has often been observed on a microgeographical scale.

Genetically based morphological differentiation among populations of marine algae must be carefully interpreted since morphological characters are commonly used as taxonomic criteria for distinguishing species (Mathieson et al., 1981). Distinguishing intraspecific ecotypic variation from interspecific variation may require additional information such as that provided by crossing studies. For example, two isolates of Ceramium were originally described as separate species based on morphological differences (Rueness, 1978). Subsequent crossing studies showed that the two species formed fertile hybrids suggesting that the morphological differences were ecotypic variation within a single species (Rueness, 1978). 


\section{PHYSIOLOGICAL DIFFERENTIATION}

Physiological ecotypes have been described for several marine algae (Table 2) and provide additional evidence for genetic differentiation among populations. Studies comparing populations from habitats with different extremes of a particular environmental parameter have been valuable for identifying physiological ecotypes in several species of plants (Bradshaw, 1971). An example of this sort of differentiation was found

Table 2. Genetically based physiological differences among populations of marine algae. $L=$ growth under common laboratory conditions, $C=$ crosses

\begin{tabular}{|llll|}
\hline \multicolumn{1}{|c}{ Species } & $\begin{array}{c}\text { Evidence } \\
\text { for genetic } \\
\text { differentiation }\end{array}$ & $\begin{array}{c}\text { Environmental } \\
\text { factor }\end{array}$ & \multicolumn{1}{c|}{ Reference } \\
\hline Bostrichia radicans & $\mathrm{L}$ & salinity & Yarish et al. (1979) \\
Caloglossa leprieurii & $\mathrm{L}$ & salinity & Yarish et al. (1979) \\
Polysiphonia urceolata & $\mathrm{L}$ & temperature & Kapraun (1979) \\
Ectocarpus siliculosus & $\mathrm{L}$ & copper & Russell \& Morris (1970) \\
E. siliculosus & $\mathrm{L}$ & salinity & Russell \& Bolton (1975) \\
E. siliculosus & $\mathrm{L}, \mathrm{C}$ & temperature & Bolton (1983) \\
Pilayella littoralis & $\mathrm{L}$ & salinity & Bolton (1979) \\
Laminaria longicruris & $\mathrm{L}, \mathrm{C}$ & nitrate & Espinoza \& Chapman (1983) \\
L. saccharina & $\mathrm{L}, \mathrm{C}$ & temperature & Lüning et al. (1978) \\
Enteromorpha intestinalis & $\mathrm{L}$ & salinity & Reed \& Russell (1979) \\
E. linza & $\mathrm{L}$ & temperature & Innes (1983) \\
Eugomontia sacculata & $\mathrm{L}$ & salinity & Wilkinson (1974) \\
Stigeoclonium spp. & $\mathrm{L}$ & salinity & Francke (1982) \\
& & & Francke \& Rheberger (1982) \\
\hline
\end{tabular}

between two populations of Ectocarpus siliculosus, one growing in an environment with a high concentration of copper on the bottom of ships and another population growing on an unpolluted rocky shore (Russell \& Morris, 1970). Strains collected from the ship population tolerated a much higher concentration of copper than strains from the rocky shore. Bradshaw (1971) suggested two possible sources of tolerant individuals for the establishment of copper tolerant populations. One source could be a low frequency of tolerant individuals already existing in many natural populations. It is also possible that copper tolerant individuals may have evolved in only a few areas of high copper concentration and spread to the bottom of copper treated ships. No information is available on the occurrence of copper tolerant individuals in rocky shore populations.

Genetic differentiation among populations of algae inhabiting different salinity environments has been well documented (Table 2). Such differentiation has been found to occur over the short distance between sites at the mouth and head of estuaries. Studies have shown that individuals collected from marine and estuarine sites have the highest growth rate under high and low salinity conditions, respectively (Table 2). Since tidal action often connects these two salinity regimes, a certain amount of migration between the sites by the two ecotypes might be expected. Most studies to date have not measured the response of enough individuals to detect if low salinity ecotypes occur at a low 
frequency in high salinity sites or vice versa. However, Bolton (1979) observed significant variation among several isolates of Pilayella littoralis from an intermediate site in an estuary suggesting that this population consisted of a mixture of ecotypes. The occurrence of genetic differentiation between low and high salinity populations of Bostrychia radicans and Caloglossa leprieurii connected by tidal action was thought to indicate that reproductive isolation must have played a role in the evolution of these salinity ecotypes (Yarish et al., 1979). However, genetic dif-erentiation can be maintained between populations even in the face of substantial gene flow (Endler, 1977). The amount of differentiation will be a function of the selection differential and the amount of gene flow between populations. The salinity response of other fitness characters, such as mortality and reproduction, will have to be measured for a large number of individuals to adequately assess the evolution of genetic differentiation between different salinity habitats.

Genetic differentiation has also been reported among populations of algae experiencing different temperature conditions (Lüning et al., 1978; Kapraun, 1979; Bolton, 1983). Bolton (1983) found that the growth and survivorship of Ectocarpus siliculosus under various temperature conditions was clinally related to the temperature conditions of the original collecting site of each isolate. The isolates had been maintained under identical laboratory conditions for several years before being tested and therefore are likely to represent genetic differences. Two hybrids from two different sets of crosses between different isolates showed a reduced rate of growth compared to their parents. Additional crosses will be necessary to understand the genetic basis of temperature tolerance among the strains.

The progeny of Enteromorpha linza collected from high and low intertidal positions showed different growth rate responses when raised under different temperatures in the laboratory (Innes, 1983). Progeny derived from high intertidal parents showed a higher growth rate than progeny from low intertidal parents when grown at $15^{\circ} \mathrm{C}$. At $24^{\circ} \mathrm{C}$ the growth rate of the high intertidal individuals increased while the low intertidal individuals showed a decrease in growth rate. Response to temperature in this species suggested that differentiation in the intertidal zone was partially associated with the temperature differences between the high and low intertidal environments. Individuals from high and low intertidal positions were also found to be genetically different at enzyme loci (Innes, 1983).

In addition to temperature and salinity variation, nutrient concentrations in the water column can vary. Espinoza \& Chapman (1983) collected individuals of Laminaria longicruris from areas of high and low nitrate concentration. Nutrient ecotypes were identified by growth rate and nitrate uptake differences under different nitrate concentrations. Reciprocal crosses showed that the ecotypes were interfertile.

\section{CROSSING STUDIES}

Crosses between individuals from different populations are useful for identifying a genetic component to observed morphological or physiological variation. The inheritance pattern of a character can usually distinguish single gene variation from polygenic variation. For example, crosses between branching morphs of Antithamnion plumula revealed that the variation was due to two alleles at a single locus with var. plumula 
dominant over var. bebbii (Rueness \& Rueness, 1975). There appeared to be no strong geographical or ecological pattern to the distribution of morphs of this species (Rueness, 1978). Genetic variation in most morphological characters is probably polygenic, requiring a quantitative genetic analysis to separate genetic variation from environmental variation. Quantitative genetic analyses in Laminaria showed that the heritability of stipe characteristics differed between sheltered and wave exposed populations (Chapman, 1974, 1975). This is an example of genetic differentiation among populations in degree of genetic control of a morphological character (Russell \& Fielding, 1981).

Many seaweed crossing studies have been used as a means of evaluating the taxonomic status of geographically separated populations. Much of this information has recently been tabulated (Mathieson et al., 1981). The interpretation of such studies is by no means straightforward. Genetic differentiation may evolve without affecting the ability of individuals to intercross. Also, intersterility does not necessarily indicate the accumulation of a large number of genic differences. Despite these problems, interpopulational crosses can provide information on genetic differentiation, if growth, survival and reproduction are quantified in the hybrids and the progeny of intercrossed hybrids. Incompatibility between populations will be expressed when the hybrids are intercrossed since the progeny will inherit various proportions of the genomes of individuals from the two original parental populations. In Lepidoptera, there is evidence that the degree of incompatibility can be positively correlated with the geographic distance between populations (Oliver, 1972).

Rueness (1973) was able to successfully cross gametophytes of Polysiphonia boldii from Texas with gametophytes of $P$. hemisphaerica from Scandinavia. However, incompatibility was expressed during meiosis in tetrasporophytes. An isolate of Ceramium strictum from Norway was found to be interfertile with an isolate of $C$. tenuicorne from the Baltic (Rueness, 1978). No reduction in fertility or survival was observed in the hybrids, the intercross of the hybrids or the backcross to the parents. Because of this compatibility the genetically based morphological and physiological differences were interpreted as ecotypic variation between individuals of the same species.

Individuals of Gigartina agardii from several geographically separated populations along the west coast of North America showed a high degree of compatibility when crossed (West et al., 1978). However, there was a suggestion that some individuals from more geographically isolated populations were less often compatible. Incompatibility was also found among some geographically separated populations of $G$. stellata (Guiry \& West, 1983). The pattern of incompatibility identified two breeding groups. One consisted of individuals from England, Wales and Ireland and the other was made up of individuals from Spain and Portugal. Individuals from both breeding groups were found in the samples from France. Morphological differences were also found between the two groups. The taxonomic status of $G$. stellata is presently under investigation (Guiry \& West, 1983).

Müller (1979) used the ability of gametes to fuse (plasmogamy) as a criterion for testing the compatibility of strains of Ectocarpus siliculosus from the Mediterranean, North Atlantic and Australia. Gamete fusion was observed between most strains except a strain from Massachusetts which was incompatible with most of the others. A strain from Texas was also partially incompatible with the other strains. It was concluded that individuals separated on a world-wide basis were genetically closely related except for a 
few populations which had diverged enough to be reproductively isolated. However, reproductively compatible strains were found to be genetically differentiated with respect to growth and survival responses under different temperature conditions (Bolton, 1983). This shows that observations on plasmogamy alone are not sufficient to estimate genetic differentiation among populations.

Reproductive compatibility between widely separated populations has also been found for species of Laminaria (Lüning et al., 1978; Bolton et al, 1983). The results of these crossing experiments suggest that northern hemisphere Laminaria are closely related. Additional information, possibly from electrophoretic variation of enzymes, will be necessary to establish if these are genetically differentiated populations of a smaller number of species than presently recognized.

\section{DISPERSAL}

Genetic differentiation among populations can be generated by random or selective forces. Any gene flow between populations will tend to counteract this differentiation. Dispersal of individuals or propagules between populations may or may not result in gene flow depending on whether individuals survive and reproduce after dispersing. Taking these limitations into consideration, measurements of dispersal capabilities can be useful for predicting the potential for gene flow between populations of a species.

Amsler \& Searles (1980) used glass slides suspended in the water column to collect seaweed spores at a site approximately $30 \mathrm{~km}$ from the coast of North Carolina. Spores of green algae were found more often in the upper part of the water column compared with spores from brown algae and red algae. The distribution of green algae spores in the upper part of the water column was thought to indicate a wider dispersal potential for these spores. The occurrence of Enteromorpha spores on the glass slides suggested that these spores dispersed from the nearest sizable population $35 \mathrm{~km}$ away. Long distance dispersal by currents may be possible in some species of Enteromorpha since spores of $E$. intestinalis have been found to be motile for up to eight days in the laboratory (Jones $\&$ Babb, 1968).

Other studies of spore dispersal in marine algae have found a much more restricted dispersal: on the order of five meters from the parent plant (Anderson \& North, 1966; Dayton, 1973; Paine, 1979; Deysher \& Norton, 1981). The observed rate of spread of Sargassum muticum suggested that this species possessed a long distance dispersal mechanism in addition to the short distance dispersal observed for germlings (Deysher \& Norton, 1981). It was postulated that detached vegetative fragments could be carried by wind and water currents. Since this species is monoecious and self-fertile, a single vegetative fragment could become fertile in the water column and colonize an area distant from the parent population. The rapid spread of Codium fragile in the eastern Atlantic may have involved a similar mechanism for long distance dispersal (Malinowski, 1974). Codium fragile reproduces by asexual swarmers which would facilitate the colonization of new areas by the floating fragments. Fragmentation may be a common mode of reproduction in algae as well as an efficient mechanism for long distance dispersal (Yarish \& Edwards, 1982). 


\section{ELECTROPHORETICALLY DETECTABLE GENETIC VARIATION}

Attempts to describe a genetic cause to observed morphological or physiological variation among populations require breeding experiments that can be laborious or impossible to conduct. Furthermore, conclusions from laboratory culture experiments assume the absence of any interaction between genotype and environment in producing observed phenotypes. This difficulty is offset somewhat by raising the same genotype under several conditions to measure any genotype by environmental interaction or growing the progeny of crosses under natural conditions in the field. A second difficulty in using genetically based morphological and physiological differences for studying genetic differentiation among populations is being able to quantify the level of differentiation. The number of genes controlling quantitative traits is rarely known (see Rueness \& Rueness, 1975 for an exception). The presence of genetic differences among several populations of a species provides no information on whether certain pairs of populations are more genetically similar than others. Similarly, crosses between individuals from geographically separated populations usually produce only an all or nothing response with little information on the level of differentiation.

Obtaining quantitative estimates of genetic differentiation has been greatly facilitated by using electrophoretic variation of proteins (usually enzyme proteins) as a means of estimating genetic variation within and between natural populations. Numerous studies have used this approach to assess genetic differentiation among populations of a variety of plant and animal species. The advantages, limitations and interpretations of electrophoretic variation have been discussed in detail (Lewontin, 1974; Avise, 1975; Nei, 1975; Gottlieb, 1977). Only some of the potential problems will be presented here.

Visualization of a particular enzyme protein after gel electrophoresis takes advantage of the specificity of the enzyme for its substrate. Since most of the enzymes used in a typical study are found in all living organisms, electrophoresis of a new species often only involves minor modifications of existing techniques. Shaw \& Prasad (1970) and Harris \& Hopkinson (1976) provide a valuable compilation of procedures for gel electrophoresis and recipes for staining a large number of enzymes. Cheney (1985) has recently outlined similar procedures for algae.

One of the requirements for an enzyme locus to be useful as a genetic marker is that it be resolved on the gel as a sharp band. Since electrophoretic variation is observed as differences in mobility, diffuse smears of enzyme activity may obscure any differences. Resolution can usually be improved by trying a number of different electrophoresis buffer systems. Monomorphic enzyme loci show a single band (designated as an electromorph) with identical mobility in all individuals sampled in a study of several populations. In a polymorphic enzyme locus, two or more electromorphs are found in a sample of diploid individuals such that homozygous and heterozygous banding patterns are observed for each individual. For example, if two electromorphs are found with fast (F) and slow (S) relative mobilities, individuals can be scored as single-banded FF and SS homozygotes and two-banded FS heterozygotes in a monomeric enzyme. The genetic interpretation that these are alleles segregating at a single locus is strengthened by performing crosses and studying the inheritance pattern of the electromorphs. Where this is not possible, as in asexually reproducing species, the different banding phenotypes should be shown to be heritable through asexual generations and not modified by environmental conditions. 
Often single individuals display several bands when stained for a particular enzyme. For example, more than one locus can be present, each coding for different molecular forms (isozymes) of an enzyme with different mobilities. Also, the subunit structure of an enzyme can result in more than two bands in heterozygous individuals. For instance, an enzyme with a dimeric subunit structure will produce three-banded heterozygotes compared to the two-banded heterozygotes for monomeric enzymes. Figure 1 is an example of electrophoretic variation for the dimeric enzyme glutamate

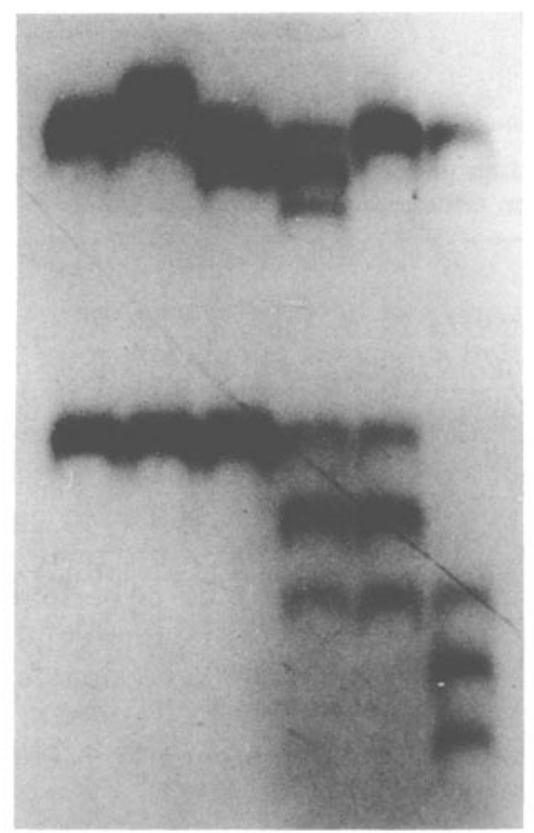

Fig. 1. Glutamate oxaloacetate transaminase (GOT) banding patterns for six individuals of Enteromorpha linza. Migration is from bottom to top in a polyacrylamide gel with GOT-1 migrating faster than GOT-2. The phenotype designations (cf. Innes \& Yarish, 1984) for GOT-1 are (1. to r.): SS, SF, SM, S'S, SS, SS. For GOT-2: FF, FF, FF, FM, FM, MS

oxaloacetate transaminase (GOT). Six individuals of Enteromorpha linza are shown with single-banded homozygous and three-banded heterozygous patterns for two GOT loci. The patterns are consistent with those expected for electrophoretically distinct alleles associated with the two loci and are heritable through asexual generations in the laboratory (Innes \& Yarish, 1984). Figure 2 shows some of the acid phosphatase (AP) banding pattern variation observed among individuals of E. linza. The patterns are also heritable through asexual generations but are not as easily interpreted as the GOT variation. Complicated banding patterns such as these would require some initial crossing experiments in a sexual species to work out the number of loci and alleles involved in producing the observed variation. Simply scoring the presence and absence of different bands would be misleading and incorrect (Gottlieb, 1977). Enzymes with uninterpretable variation should be omitted from any analysis of genetic differentiation among populations. 


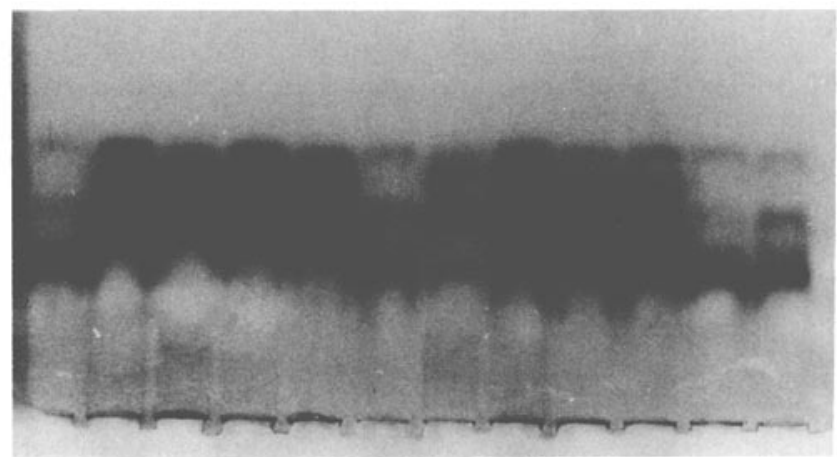

Fig. 2. Acid phosphatase banding patterns for 12 individuals of Enteromorpha linza. Migration is from bottom to top in a polyacrylamide gel

Once polymorphic enzyme loci have been resolved for a species, a survey of the distribution of genetic variation among populations can be carried out. Significant differentiation in the frequency of the variants among populations may be the result of selection by the local environment or random factors accompanied by restricted gene flow. Independent information on the dispersal distances relative to distances between differentiated populations is valuable for discriminating between these two explanations. However, as pointed out by Burton (1983) in a review of genetic differentiation among populations of marine invertebrates, high dispersal does not necessarily imply high gene flow. Despite some of the problems of interpreting patterns of differentiation, electrophoretically detectable enzyme variation is invaluable for quantifying the level of genetic differentiation among populations. The results of such surveys provide an assessment of the geographic scale of differentiation and often suggest testable explanations for the observed pattern.

The use of enzyme variation to study genetic differentiation in populations of marine benthic algae has been very limited compared with other organisms (Cheney, 1985). A systematic study of species of Eucheuma using electrophoretic variation (Cheney \& Babbel, 1978) also included samples from three populations of two of the species (Table 3). Unfortunately, the data presented were pooled results of both haploid and diploid reproductive plants with vegetative plants of unknown ploidy. The population differentiation observed for such pooled data may simply reflect different proportions of the haploid and diploid stages in the sample rather than true genetic differences. Future studies should report genetic data for each life-history stage separately. This would also provide some empirical data to compare with recent models on the maintenance of genetic variation in species with alternating haploid and diploid stages (Ewing, 1977). Another difficulty with this study was the inclusion of several enzyme bands with variable expression among individuals. Enzymes with known nongenetic variation should be discarded from any analysis.

Malinowski (1974) resolved 14 enzyme loci in samples of the introduced species Codium fragile from ten sites in Long Island Sound and southeastern Massachusetts (Table 3). Ten of the loci were monomorphic. The remaining four showed banding patterns which were interpreted as fixed heterozygotes in all 500 individuals. It was 
Table 3. Electrophoretic variation among populations of marine algae

\begin{tabular}{|lcccl|}
\hline \multicolumn{1}{|c}{ Species } & $\begin{array}{c}\text { No. of } \\
\text { loci }\end{array}$ & $\begin{array}{c}\text { No. of } \\
\text { polymorphic } \\
\text { loci }\end{array}$ & $\begin{array}{c}\text { No. of } \\
\text { populations }\end{array}$ & Reference \\
\hline Codium fragile & 14 & 4 & 14 & Malinowski (1974) \\
Eucheuma isiforme & $7^{*}$ & 4 & 3 & Cheney \& Babbel (1978) \\
E. nudum & $7^{*}$ & 4 & 3 & Miura et al. (1979) \\
Porphyra yezoensis & 8 & 6 & 11 & Innes (1983) \\
$\quad$ Wild population & 8 & 0 & 9 & \\
$\quad$ Cultured populations & 8 & 5 & 16 & \\
Enteromorpha linza & 5 & & & \\
- Loci with variable expression not included & &
\end{tabular}

concluded that these populations consisted of a single asexually reproducing genotype. Lack of genetic diversity may be the result of a small number of founding individuals when this species was introduced to the area before 1957 (Malinowski, 1974). Additional samples from Maine, California, British Columbia and England revealed some genotypic diversity within each sample but the occurrence of fixed heterozygotes suggested extensive asexual reproduction in these populations as well. The pattern of genetic differentiation grouped the California and British Columbia samples together with the remaining samples forming a second group (Fig. 3). The pattern of differentiation was used as evidence that Europe was the source of introduction of this species to eastern North America.

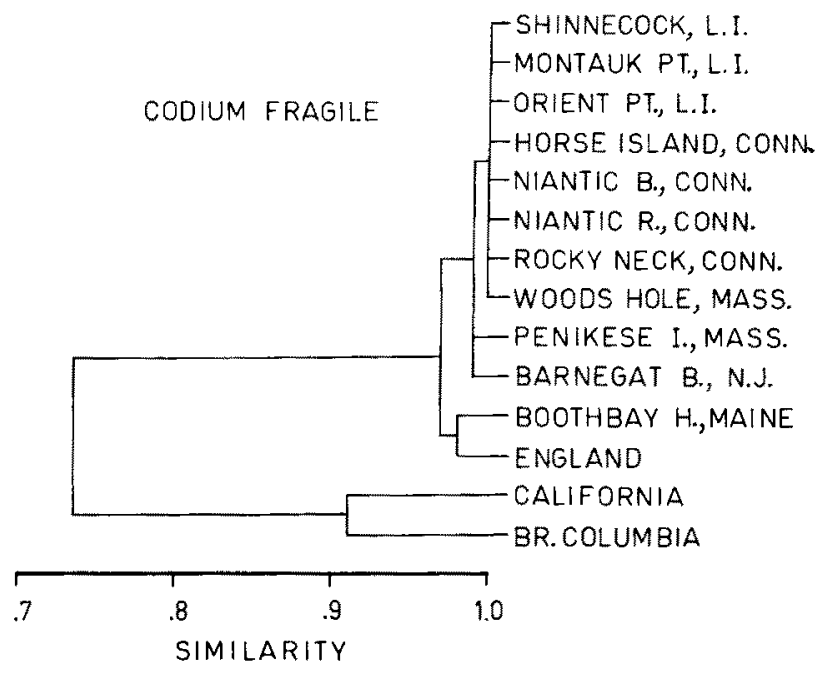

Fig. 3. The clustered pattern of genetic similarity among population samples of Codium fragile. Genetic similarity calculated from enzyme gene frequency data using Nei's identity (Nei, 1972). 
Miura et al. (1979) studied the pattern of genetic differentiation among populations of wild and cultured Porphyra yezoensis (Table 3). Six of the eight loci resolved were polymorphic but only in the wild populations. The occurrence of only single-banded variation among individuals suggested that the thallus sampled represented a haploid stage in the life history of this species. There was significant genetic differentiation among the wild and cultured populations (Fig. 4). However, no obvious correlation with geographic distance between populations was evident (Miura et al., 1979).

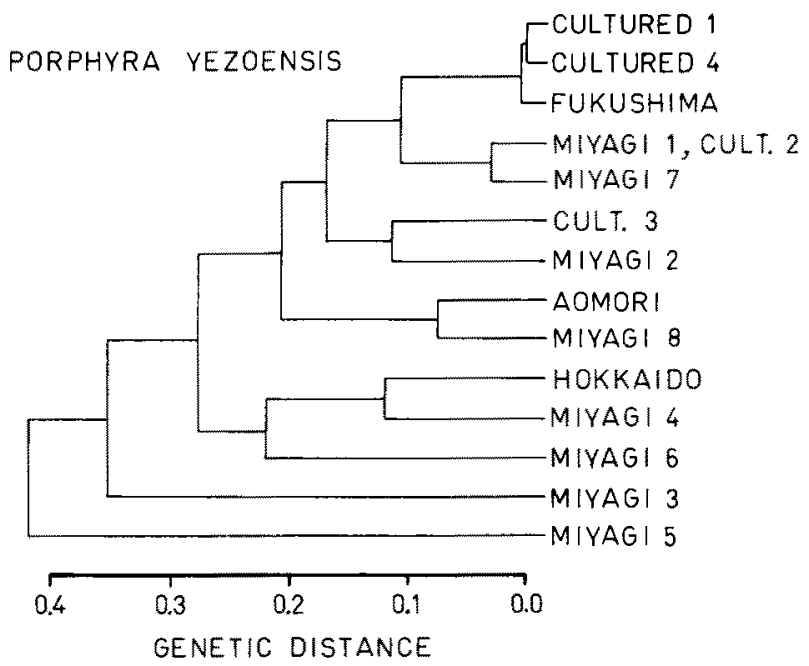

Fig. 4. The clustered pattern of genetic distance among wild and cultured populations of Porphyra yezoensis. Locality designations condensed from Fig. 2 of Miura et al. (1979). Miyagi 1 to 8 , Dairiseki-kaigan, Kesennuma, Iwaizaki, Konorihama, Tsukahama, Koyatori, North Sannojima, and South Sannojima, respectively. Genetic distance calculated from enzyme gene frequency data using a formula given in Miura et al. (1979)

The genetic structure of populations of Enteromorpha linza from Long Island Sound has been examined using five polymorphic enzyme loci (Table 3; Innes, 1983). All of the phenotypic variation observed was clearly resolved and conformed to homozygous and heterozygous patterns expected for electrophoretically distinct alleles associated with each locus. Banding patterns were shown to be heritable with no segregation observed for heterozygous phenotypes. Information on variation among individuals in several populations, together with the absence of segregation in heterozygous individuals, suggested that reproduction in Long Island Sound was primarily if not exclusively asexual (Innes \& Yarish, 1984). Sixteen localities were sampled in 1982 and significant genetic differentiation was found for each of the five loci separately as well as when the information was incorporated into a multilocus measure (Innes, 1983). Genetic differentiation among localities was summarized as a minimum spanning tree connecting localities with the shortest genetic distance (most genetically similar), before connecting all localities, such that the total length of the tree was minimized (Sneath \& Sokal, 1973). Figure 5 compares the genetic distance among localities, as summarized by this tree, with the geographic distance among the localities. There was little concordance 


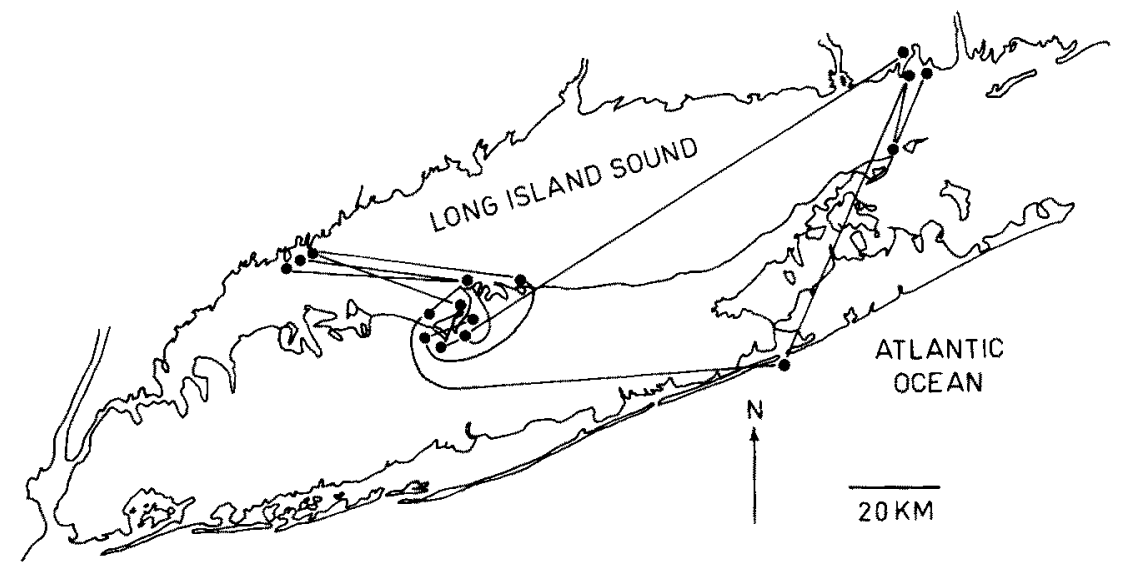

Fig. 5. The relationship between genetic distance and geographic distance using a minimum spanning tree (explained in the text) for samples of Enteromorpha linza from several localities in Long Island Sound. Genetic distance calculated as the complement of Hedrick's similarity (Hedrick, 1971, 1975) for a multilocus measure based on variation for five enzyme loci (Innes, 1983). Lines connect localities separated by the smallest genetic distance

between genetic distance and geographic distance since many adjacent localities were only connected indirectly.

Some of genetic differentiation observed among localities of $E$. linza appeared to be related to salinity differences at the localities. Samples from four geographically separated localities with reduced salinity were genetically similar and formed a group distinct from localities with higher salinity (Innes, 1983). The differentiation between high and low salinity localities occurred within a few hundred meters. Genetic differentiation on microgeographic scale was also found between high and low positions in the intertidal zone (Innes, 1983).

\section{DISCUSSION}

The results of the studies described here provide evidence for extensive genetic differentiation among populations of several species of marine algae. Genetically based morphological and physiological differentiation associated with variation in a particular environmental parameter suggests that variation in these characteristics evolved as an adaptive response to local conditions. The genetic features of this adaptive process can be analyzed further by crossing the different ecotypes in sexually reproducing species.

Crossing studies between geographically separated individuals are more useful as a taxonomic tool than as a means of evaluating genetic differentiation since populations can become genetically divergent without any loss of interfertility. Crossing experiments can only be a useful approach for quantifying genetic differentiation if information other than interfertility is obtained. Such experiments would include measurements of the degree of interfertility, survival and fertility of the hybrids as well as the progeny from intercrossed and backcrossed hybrids. This approach would detect genetic differentiation among populations by the degree of incompatibility expressed when blocks of genes from representatives of two populations are combined in the same individual. 
The much lower growth rate of hybrids between two geographically different strains of Ectocarpus siliculosus may be the result of genetic incompatibility (Bolton, 1983).

The analysis of morphological and physiological variation among populations as well as crossing studies requires extensive observations under several environmental conditions. Electrophoretically detectable genetic variation offers a relatively easy means of quantifying the level and pattern of genetic variation among populations. Independent information on the rate of dispersal between populations is often needed to distinguish between selective and random explanations for the observed differentiation. Alternatively, variation at enzyme loci associated with variation in specific environmental parameters has been used as evidence for selectively maintained differentiation. Such observations require additional experiments, similar to those used to identify physiological ecotypes, in order to show that the association is more than a simple correlation.

The genetic differentiation observed among populations of $E$. linza in Long Island Sound may be partially due to its asexual mode of reproduction. A single individual colonizing an area could establish a population in a short time by reproducing asexually. Such founder events in this species may explain some of the observed differentiation not associated with variation in habitat salinity. More species of algae representing a variety of life history types should be studied before generalizations are made about the relationship between the genetic structure of populations and their life history. It is interesting to note that significant genetic differentiation was also found among presumedly sexually reproducing populations of Porphyra yezoensis (Miura et al., 1979).

Genetic markers are useful for investigating the genetic relationship among distinct life-history stages in laboratory culture studies (van der Meer \& Todd, 1980). Haploid and diploid stages can be identified as well as the stage where meiosis occurs. The life history of many species of algae includes asexual as well as sexual reproduction. Since sexual and asexual reproduction have different consequences on the distribution of genetic variation within a population, information on the organization of genetic variation among individuals can provide estimates of the relative frequency of each mode of reproduction. Such an approach has the advantage of studying the life history of a species under natural conditions and can supplement observations from laboratory culture.

Significant genetic differentiation among populations can be interpreted as intraspecific variation or variation indicative of taxonomically distinct individuals. Crossing studies may help distinguish these two alternative explanations but the common occurrence of successful crosses between species of plants (Stebbins, 1950) limits the usefulness of this approach. Furthermore, little is known of speciation in algae and there will likely be degrees of taxonomic differentiation from the population to the species level. Electrophoretic data have been useful for studying the degree of genetic similarity between individuals of various taxonomic levels (Avise, 1975). There are presently no similar studies for species of algae that can be used to relate genetic differentiation with taxonomic separation.

The evidence for genetic differentiation among populations of marine algae has been obtained using a variety of methods. Different advantages and disadvantages are associated with each method such that a combination of methods will remain the best approach to studying evolutionary problems in populations of marine algae. 
Acknowledgements. I am grateful to P. Hebert, L. Hermanutz and A. Mathieson for their comments on the manuscript. I wish to acknowledge a travel grant from the Foundation "Groninger Universiteitsfonds" and a postdoctoral fellowship from the Natural Sciences and Engineering Research Council of Canada. I would like to thank Professor Dr. C. van den Hoek, Dr. Charles Yarish and the members of the Departments of Marine Biology and Genetics, University of Groningen (The Netherlands) for their hospitality during my visit.

\section{LITERATURE CITED}

Amsler, C. D. \& Searles, R. B, 1980. Vertical distribution of seaweed spores in a water column offshore of North Carolina. - J. Phycol. 16, 617-619.

Anderson, E. K. \& North, W. J., 1966. In situ studies of spore production and dispersal in the giant kelp, Macrocystis. - Proc. int. Seaweed Symp. 5, 73-86.

Avise, J. C., 1975. Systematic value of electrophoretic data. - Syst. Zool. 23, 465-481.

Bolton, J. J., 1979. Estuarine adaptation in populations of Pilayella littoralis (L.) Kjellm. (Phaeophyta, Ectocarpales). - Estuar. coast. mar. Sci. 9, 273-280.

Bolton, J. J., 1983. Ecoclinal variation in Ectocarpus siliculosus (Phaeophyceae) with respect to temperature growth optima and survival imits. - Mar. Biol. 73, 131-138.

Bolton, J. J., Germann, I. \& Lüning, K., 1983. Hybridization between Atlantic and Pacific representatives of the section Simplices of Laminaria (Phaeophyta). - Phycologia 22, 133-140.

Bradshaw, A. D., 1971. Plant evolution in extreme environments. In: Ecological genetics and evolution. Ed. by R. Creed. Blackwell, Oxford, 20-50.

Burton, R. S., 1983. Protein polymorphisms and genetic differentiation of marine invertebrate populations. - Mar. Biol. Lett. 4, 193-206.

Chapman, A. R. O., 1974. The genetic basis of morphological differentiation in some Laminaria populations. - Mar. Biol. 24, 85-91.

Chapman, A. R. O., 1975. Inheritance of mucilage canals in Laminaria (Section Simplices) in eastern Canada, - Br. phycol. J. 10, 219-223.

Cheney, D. P., 1985. Electrophoresis. In: Handbook of phycological methods: Ecological methods for macroalgae. Ed. by M. Littler \& D. Littler. Cambridge Univ. Press, Cambridge (in press.)

Cheney, D. P. \& Babbel, G., 1978. Biosystematic studies of the red algal genus Euchema. I. Electrophoretic variation among Florida populations. - Mar, Biol. 47, 251-264.

Dayton, P. K., 1973. Dispersion, dispersal and persistence of the annual intertidal alga Postelsia palmaeformis Ruprecht. - Ecology 54, 433-438.

Deysher, L. \& Norton, T. A., 1981. Dispersal and colonization in Sargassum muticum.- J. exp. mar. Biol. Ecol. 56, 179-196.

Druehl, L. D. \& Kemp, L., 1982. Morphological and growth responses of geographically isolated Macrocystis integrifolia populations when grown in a common environment. - Can. J. Bot. 60 , $1409-1413$.

Ehrlich, P. R. \& Raven, P. H., 1969. Differentiation of populations. - Science, N.Y. 165, 1228-1232.

Endler, J. A., 1977. Geographic variation, speciation, and clines. Princeton Univ. Press, Princeton, $246 \mathrm{pp}$.

Espinoza, J. \& Chapman, A. R. O., 1983. Ecotypic differentiation of Laminaria longicruris in relation to seawater nitrate concentration. - Mar. Biol. 74, 213-218.

Ewing, E. P., 1977. Selection at the haploid and diploid phases: Cyclical variation. - Genetics 87 , 195-208.

Francke, J. A., 1982. Morphological plasticity and ecological range in three Stigeoclonium species (Chlorophyceae; Chaetophorales). - Br. phycol. J. 17, 117-134.

Francke, J. A. \& Rheberger, L. J., 1982. Euryhaline ecotypes in some species of Stigeoclonium. - Br. phycol. J. 17, 135-145.

Gerard, V. A. \& Mann, K. H., 1979. Growth and production of Laminaria longicruris (Phaeophyta) populations exposed to different intensities of water movement. $-J$. Phycol. 15, 33-41.

Gottlieb, L. D., 1977. Electrophoretic evidence and plant systematics. - Ann. Mo. bot. Gdn 64, $161-180$.

Guiry, M. D. \& West, J. A., 1983. Life history and hybridization studies on Gigartina stellata and Petrocelis cruenta (Rhodophyta) in the North Atlantic. - J. Phycol. 19, 474-494. 
Harris, H. \& Hopkinson, D. A., 1976. Handbook of enzyme electrophoresis in human genetics. North-Holland Publ., Amsterdam.

Hedrick, P. W., 1971. A new approach to measuring genetic similarity. - Evolution 25, 276-280.

Hedrick, P. W., 1975. Genetic similarity and distance: comments and comparisons. - Evolution 29, 362-366.

Innes, D. J., 1983. Genetic variation and adaptation in the asexually reproducing alga Enteromorpha linza. Ph. D. Diss., State Univ. of New York, 203 pp.

Innes, D. J. \& Yarish, C., 1984. Genetic evidence for the occurrence of asexual reproduction in populations of Enteromorpha linza (L.) J. Ag. (Chlorophyta, Ulvales) from Long Island Sound. Phycologia 23, 311-320.

Jones, W. E. \& Babb, M. S., 1968. The motile period of swarmers of Enteromorpha intestinalis (L.) Link. - Br. phycol. Bull. 3, 525-528.

Kapraun, D. F, 1979. Comparative studies of Polysiphonia urceolata from three North Atlantic sites. - Norw. J. Bot. 26, 269-276.

Lewontin, R. C., 1974. The genetic basis of evolutionary change. Columbia Univ. Press, New York, $346 \mathrm{pp}$.

Lüning, K., Chapman, A. R. O. \& Mann, K. H., 1978. Crossing experiments in the non-digitate complex of Laminaria from both sides of the Atlantic. - Phycologia 17, 293-298.

Malinowski, K. C., 1974. Codium fragile: The ecological and population biology of a colonizing species. Ph. D. Diss., Yale Univ., 135 pp.

Mathieson, A. C., Norton, T, A. \& Neushul, M., 1981. The taxonomic implications of genetic and environmentally induced variations in seaweed morphology. - Bot. Rev. 47, 313-347.

Meer, J. P. van der \& Todd, E. R., 1980. The life history of Palmeria palmata in culture. A new type for the Rhodophyta. - Can J. Bot. 58, 1250-1256.

Miura, W., Fujio, Y. \& Suto, S., 1979. Genetic differentiation between the wild and cultured populations of Porphyra yezoensis. - Tohoku J, agric. Res. 30, 114-125.

Müller, D. G., 1979. Genetic affinity of Ectocarpus siliculosus (Dillw.) Lyngb. from the Mediterranean, North Atlantic and Australia. - Phycologia 18, 312-318.

Nei, M., 1972. Genetic distance between populations. - Am. Nat. 106, 283-292.

Nei, M., 1975. Molecular population genetics and evolution. North-Holland Publ., Amsterdam, $288 \mathrm{pp}$.

Norton, T. A., Mathieson, A. C. \& Neushal, M., 1981. Morphology and environment. In: The biology of seaweeds. Ed. by C. S. Lobban \& M. J. Wynne. Blackwell, Oxford, 421-451.

Norton, T. A., Mathieson, A. C. \& Neushal, M., 1982. A review of some aspects of form and function in seaweeds. - Botanica mar. 25, 501-510.

Oliver, C. G., 1972. Genetic and phenotypic differentiation and geographic distance in four species of Lepidoptera. - Evolution 26, 221-241.

Paine, R. T., 1979. Disaster, catastrophe, and local persistence of the sea palm Postelsia palmaeformis. - Science, N. Y. 205, 685-687.

Paula, E. J. de \& Oliveira, E. C. de, 1982. Wave exposure and ecotypical differentiation in Sargassum cymosum (Phaeophyta, Fucales). - Phycologia 21, 145-153.

Reed, R. H. \& Russell, G., 1979. Adaptation to salinity stress in populations of Enteromorpha intestinalis (L.) Link. - Estuar. coast. mar. Sci. 8, 251-258.

Rueness, J., 1973. Speciation in Polysiphonia (Rhodophyceae, Ceramiales) in view of hybridization experiments: $P$. hemisphaerica and $P$. boldii. - Phycologia 12, 107-109.

Rueness, J., 1978. Hybridization in red algae. In: Modern approaches to the taxonomy of Red and Brown Algae. Ed. by D. E. G. Irvine \& J. H. Price. Acad. Press, London, 247-262.

Rueness, J. \& Rueness, M., 1975. Genetic control of morphogenesis in two varieties of Antithamnion plumula (Rhodophyceae, Ceramiales). - Phycologia 14, 81-85.

Russell, G. \& Bolton, J. J, 1975. Euryhaline ecotypes of Ectocarpus siliculosus (Dillw.) Lyngb. Estuar. coast. mar. Sci. 3, 91-94.

Russell, G. \& Fielding, A. H., 1981. Individuals, populations and communities. In: The biology of seaweeds. Ed. by C. S. Lobban \& M. J. Wynne. Blackwell, Oxford, 394-411.

Russell, G. \& Morris, O. P., 1970. Copper tolerance in the marine fouling alga, Ectocarpus siliculosus. - Nature, Lond. 228, 288-289. 
Shaw, C. \& Prasad, R., 1970. Starch gel electrophoresis of enzymes - A compilation of recipes. Biochem. Genet. 4, 297-320.

Sideman, E. J. \& Mathieson, A. C., 1983. Ecological and genecological distinctions of a high intertidal dwarf form of Fucus distichus (L.) Powell in New England. - J. exp. mar. Biol. Ecol. 72, $171-188$.

Silva, M. W. R. N. de \& Burrows, E. M., 1973. An experimental assessment of the status of the species Enteromorpha intestinalis (L.) Link and Enteromorpha compressa (L.) Grev. - J. mar. biol. Ass. U. K. 53, 895-904.

Sneath, P. H. A. \& Sokal, R. R., 1973. Numerical taxonomy, Freeman, San Francisco, 573 pp.

Stebbins, G. L., 1950. Variation and evolution in plants. Columbia Univ. Press, New York, 643 pp.

Sundene, O., 1975. Experimental studies on form variation in Antithamnion plumula (Rhodophyceae). - Norw, J. Bot. 22, 35-42.

West, J. A., Polanshek, A. R. \& Shevlin, D. E., 1978. Field and culture studies on Gigartina agardii (Rhodophyta). - J. Phycol. 14, 416-426.

Wilkinson, M., 1974. Investigations on the autecology of Eugomontia sacculata Kornm. a shell boring alga. - J. exp. mar. Biol. Ecol. 16, 19-27.

Yarish, C. \& Edwards, P., 1982. A field and cultural investigation of the horizontal and seasonal distribution of estuarine red algae of New Jersey. - Phycologia 21, 112-124.

Yarish, C., Edwards, P. \& Casey, S., 1979. A culture study of salinity responses in ecotypes of two estuarine red algae. - J. Phycol. 15, 341-346. 